\title{
New developments in the era of viral hepatitis vaccines
}

\author{
Viral hepatit aşılarında yeni gelişmeler
}

Merve POYRAZ, Osman Cavit ÖZDOĞAN

\begin{abstract}
Chronic hepatitis $\mathrm{B}$ and hepatitis $\mathrm{C}$ infections are major health problems in the world. Therefore, prevention of the transmission of the viral infections gets higher priority. Development of hepatitis $B$ vaccines by recombinant technology provide higher prevention rates. However, this success could not be achieved with hepatitis $\mathrm{C}$ vaccine. The present review discusses recent developments for hepatitis $\mathrm{B}$ and $\mathrm{C}$ vaccines.
\end{abstract}

Keywords: New vaccines, Hepatitis B, Hepatitis C

\section{ÖZ}

Kronik Hepatit B ve C enfeksiyonları tüm dünyada major bir sağlık sorunudur. $\mathrm{Bu}$ nedenle enfeksiyonun geçişinin önlenmesi büyük önem kazanmaktadır. Rekombinant yol ile geliştirilen Hepatit B aşısı ile çok başarılı koruyuculuk sağlanırken, aynı başarı Hepatit $\mathrm{C}$ enfeksiyonu için geliştirilen aşı çalışmalarında gerçekleştirilememiştir. $\mathrm{Bu}$ derlemede hepatit $\mathrm{B}$ ve $\mathrm{C}$ enfeksiyonları için geliştirilen aşı çalışmaları hakkında son gelişmeleri tartışılmıştır.

Anahtar kelimeler: Yeni aşılar, Hepatit B, Hepatit C
Merve Poyraz, Osman Cavit Özdoğan (丣)

Sub-department of Gastroenterology, Department of Internal Medicine, School of Medicine, Marmara University Education and Research Hospital, Istanbul, Turkey

e-mail:osmanozdogan@yahoo.com

\section{Introduction}

Chronic hepatitis B virus (HBV) and hepatitis C virus (HCV) infections are the main etiologic factors of chronic liver diseases in the world. It is known that 400 million people are infected with HBV and 170 million people are infected with $\mathrm{HCV}$ infection worldwide [1,2]. Recent developments in HBV treatment provide sustained HBV infection suppression during on medication, however stopping the treatment causes increase in viral replication together with the flare up of the hepatitis. Treatment of chronic liver diseases and complications requires large amounts of costs, therefore prevention of these infections needs high priority in the control of these infectious diseases. In addition to reducing the routes of transmission, progression in the development of viral vaccines is also important for the control of the burden of HBV and HCV infections. After the isolation of HBV virus, development of HBV vaccines progressed rapidly and achieved $90 \%$ of prophylaxis after the vaccination. However, development of an effective vaccine against HCV still cannot be achieved. Yet, almost $100 \%$ cure rates are achieved in the era of new direct acting anti-viral (DAA) drugs. In this review, current situation and future directions will be discussed in relation to $\mathrm{HBV}$ and $\mathrm{HCV}$ vaccines.

\section{Hepatitis B vaccines}

Hepatitis B vaccines were firstly developed in France and USA through the deactivation of HBV from the serum of infected people by heating or treating with formaldehyde in 1981. However, by concerning the other viral transmission risks, usage of these vaccines mostly abandoned in all over the world. In 1986, recombinant technology was undertaken to produce HBs polypeptides from the yeast cells and second generation HBV vaccines were developed by replacing 
these polypeptides into the small particules [3,4]. By this methodology, the manufacturers were capable of producing safe and unlimited amount of vaccines. In the begining of the 90'ies third generation of HBV vaccines were developed and replaced the second generations in the market which were produced by more advanced recombinant technology. These vaccines are produced from the mammalian cells or yeast cells (Sacchoromyces cerevisiae). The vaccines Recombivax (Merck, USA) and Engerix (SmithKline Biologicals, Belgium) consist of non-glycolized, small $\mathrm{S}$ envelope proteins produced by yeast cells, whereas vaccines produced from mammalian cells (Chinese Hamster Ovarian cells) contain $\mathrm{S}$ and Pre-S2 + S envelope proteins (GenHevac B). In addition there are two more vaccines from mammalian cells that contain Pre-S1 and Pre-S2 . These Pre-S1 and Pre-S2 envelope proteins significantly increase the amount of $\mathrm{T}$ helper cell immune response. Additionally, antibodies induced by Pre-S2 proteins prevent HBV adhesion, penetration and endocytosis capacity [5]. Also, HBV vaccines combined with hepatitis A vaccines (Twinrix) are applied in 0-7-and 21th days followed by rappel after a year [6-8].

Global HBV vaccine application program was started in 1990'ies in high HBV prevalance countries whereas Turkey involved in the program in 1998 by starting vaccination to all newborns. Catch-up vaccination is another program which indicates $\mathrm{HBV}$ vaccination at anytime and at any age in children below 19 years old. The other risky groups that should be vaccinated for HBV are those who have multipartners and homosexual relations, i.v drug users, who live at the same house with the HBV carriers, health care workers, who have chronic liver, renal and lung diseases, who have diabetes etc.

After completing the 3 doses schedule of HBV vaccination, efficacy should be checked by testing AntiHBs antibodies in the serum after 2-3 months of completing the vaccination schedule. Anti-HBs titer above $10 \mathrm{mIU} / \mathrm{mL}$ indicates that $95 \%$ effective immune response is provided by the vaccine $[9,10]$. Response rates are decreased by the increased age, having chronic renal failure, immune deficiency, etc. Second HBV vaccination schedule should be performed for non-responder individuals. For the patients with chronic renal failure or immune deficiency, double doses can be used for the second vaccination [11-13].

\section{Recent Developments in HBV Vaccine Era}

The aim of innovations in HBV vaccines is to increase the response rates to $100 \%$ for all individuals and immune deficiency patients, to make the application routes more comfortable such as oral or nasal routes instead of intramuscular or subcutaneous applications and to combine with the other vaccines [14]. One of the recently developed vaccine (HEPLISAV) which contains immune stimulant phosphorothioate oligodeoxyribonucleotide provides significantly higher response rates when compared with other third generation vaccines $[15,16]$. Also there are other studies by adding new adjuvants to HBV vaccine such as interferons, interleukins, etc. These adjuvant containing vaccines can be used in immune deficient patients to increase the immune response. The other vaccine developments are aimed to decrease the application quantities or the application routes such as only one injection vaccines are produced by capsulation of HBV surface antigen into the polymers which provides slow release of HBV surface antigen [17]. However, there are no human studies with those newly developed vaccines. There are also ongoing studies of oral, inhalation and intradermal applications of $\mathrm{HBV}$ vaccines as well [18-20]. Hepatitis B vaccine response is usually weak in chronic renal failure patients (CRF) so new adjuvant containing vaccines were also tested in those patients with good results, however these vaccines are not available in clinical practice right now. The other important subject is the use of adjuvant containing vaccines in chronic hepatitis $B$ patients in order to increase the viral suppression. Products containing MPL and MF59 have prosperous results in phase 1 studies but needs further studies [21-26].

\section{Hepatitis C Vaccine}

Hepatitis $\mathrm{C}$ is a major health problem in all over the world and probably $2 \%$ of the world population is infected by $\mathrm{HCV}$ infection. Large prevalence study which was done by Turkish Association for the Study of Liver Disease (TASL) showed that $1 \%$ of Turkish population is infected by HCV infection [27]. During the last 5 years, enormous amount of progress has been done in the treatment of HCV infection, and almost $100 \%$ sustained virologic clearance is achieved by the recently developed oral drugs. However, these drugs are very expensive and small amount of infected people are aware of their infection. So primary prevention is still very important which includes HCV vaccination. However, although hopeful research and studies are conducted, until now there is no effective $\mathrm{HCV}$ vaccine in the market. One of the main factor is the variability of HCV RNA called as quasispecies which protects itself to the neutralizing antibodies. In the development of $\mathrm{HCV}$ vaccines, two major 
genomic structure can be targeted which are E1/E2 proteins and non-structural proteins. Recently developed vaccine that consisted both E1/E2 proteins and MF59 as an adjuvant showed favorable results on chimpanzees and phase 1 studies are ongoing on humans [28,29]. The other point is to increase the $\mathrm{T}$ cell specific response to $\mathrm{HCV}$ virus by adding some kind of adjuvant molecules to the vaccine [30].

In conclusion, although large number of approaches have been pursued to develop HBV vaccines, same achievements could not be reached in HCV vaccines but by the new oral antiviral drugs HCV eradication is almost completely probable.

\section{Key Points}

- After the isolation of Hepatitis B, vaccine studies progressed rapidly and recombinant $\mathrm{HBV}$ vaccines achieved $9 \%$ of prophylaxis rates after the vaccination.

- Innovations in HBV vaccines are to increase the response rates to $100 \%$ for all individuals and immune deficiency patients, and to make the application routes more comfortable.

- Although hopeful research and studies are conducted, until now there is no effective $\mathrm{HCV}$ vaccine in the market.

\section{References}

1. McMahon BJ. Epidemiology and natural history of hepatitis B. Semin Liver Dis 2005; 25 Suppl 1:3.

2. Lavanchy D. Hepatitis B virus epidemiology, disease burden, treatment, and current and emerging prevention and control measures. J Viral Hepat 2004; 11:97.

3. Szmuness W, Stevens CE, Harley EJ, et al. Hepatitis B vaccine: demonstration of ef cacy in a controlled clinical trial in a high-risk population in the United States. N Eng J Med 1980;303:833-4.

4. McAleer WJ, Buynack EB, Maigetter RZ, Wampler DE, Miller WJ, Hilleman MR. Human hepatitis B vaccine from recombinant yeast. Nature 1984;307:178-80.

5. Young MD, Schneider DL, Zuckerman AJ, Du W, Dickson B, Maddrey WC, US Hepacare Study Group, Adult hepatitis $B$ vaccination using a novel triple antigen recombinant vaccine. Hepatology 2001;34:372.

6. Rendi-Wagner P, Kundi M, Stemberger H, et al. Antibodyresponse to three recombinant hepatitis $\mathrm{B}$ vaccines: comparative evaluation of multicenter travel-clinic based experience. Vaccine 2001; 19:2055-60.

7. Blatter M, Joines R, Resinger K, et al. An open, randomized, controlled study to evaluate the safety and immunogenicity of SmithKline Beecham Biologicals' combined hepatitis A/ hepatitis B (Twinrix $\left.{ }^{\circledR}\right)$ vaccine in adults (abstract 1629). In: Program and abstracts of the 39th Interscience Conference on Antimicrobial Agents and Chemotherapy (San Francisco), American Society for Microbiology, Washington, DC 1999:394.

8. Abraham B, Parenti D. Antibody production in response to hepatitis B surface antigen in a combination hepatitis A/ hepatitis B vaccine. J Infect Dis 2000; 182:1005-6.

9. Hadler SC, Francis DP, Maynard JE, et al. Long-term immunogenicity and efficacy of hepatitis $\mathrm{B}$ vaccine in homosexual men. N Engl J Med 1986; 315:209-14.

10. Poland GA. Hepatitis B immunization in health care workers. Dealing with vaccine nonresponse. Am J Prev Med 1998; 15:73-7.

11. Propst T, Propst A, Lhotta K, et al. Reinforced intradermal hepatitis $\mathrm{B}$ vaccination in hemodialysis patients is superior in antibody response to intramuscular or subcutaneous vaccination. Am J Kidney Dis 1998; 32:1041-5.

12. Peces R, de la Torre M, Alcázar R, Urra JM. Prospective analysis of the factors influencing the antibody response to hepatitis B vaccine in hemodialysis patients. Am J Kidney Dis 1997; 29:239-45.

13. Alper CA, Kruskall MS, Marcus-Bagley D, et al. Genetic prediction of nonresponse to hepatitis $\mathrm{B}$ vaccine. $\mathrm{N}$ Engl $\mathrm{J}$ Med 1989; 321:708-12.

14. Makidon PE, Bielinska AU, Nigavekar SS, et al. Preclinical evaluation of a novel nanoemulsion-based hepatitis B mucosal vaccine. PLoS One 2008; 3:e2954. doi: 10.1371/ journal.pone.0002954

15. Halperin SA, Ward B, Cooper C, etal. Comparison of safety and immunogenicityoftwo doses of investigationalhepatitis Bvirus surface antigen co-administered with an immunostimulatory phosphorothioate oligodeoxyribonucleotide and three doses of a licensed hepatitis B vaccine in healthy adults 18-55 years of age. Vaccine 2012; 30:2556-63. doi: 10.1016/j. vaccine.2012.01.087

16. Sablan BP, Kim DJ, Barzaga NG, et al. Demonstration of safety and enhanced seroprotection against hepatitis B with investigational HBsAg-1018 ISS vaccine compared to a licensed hepatitis B vaccine. Vaccine 2012;30:2689-96. doi: 10.1016/j.vaccine.2012.02.001

17. Singh M, Li XM, McGee JP, et al. Controlled release microparticles as a single dose hepatitis B vaccine: evaluation of immunogenicity in mice. Vaccine 1997; 15:475-81.

18. Rahman F, Dahmen A, Herzog-Hauff S, et al. Cellular and humoral immune responses induced by intradermal or intramuscular vaccination with the major hepatitis B surface antigen. Hepatology 2000; 31:521-7.

19. Rault R, Freed B, Nespor S, Bender F. Efficacy of different hepatitis $\mathrm{B}$ vaccination strategies in patients receiving hemodialysis. ASAIO J 1995; 41:M717.

20. Fabrizi F, Dixit V, Magnini M, et al. Meta-analysis: intradermal vs. intramuscular vaccination against hepatitis $\mathrm{B}$ virus in patients with chronic kidney disease. Aliment Pharmacol Ther 2006; 24:497-506.

21. Quiroga JA, Carreño V. Interferon and hepatitis B vaccine in haemodialysis patients. Lancet 1989; 1:1264.

22. Jungers P, Devillier P, Salomon H, et al. Randomised placebo-controlled trial of recombinant interleukin-2 in chronic uraemic patients who are non-responders to hepatitis B vaccine. Lancet 1994; 344:856. 
23. Thoelen S, Van Damme P, Mathei C, et al. Safety and immunogenicity of a hepatitis $B$ vaccine formulated with a novel adjuvant system. Vaccine 1998; 16:708.

24. Traquina P, Morandi M, Contorni M, Van Nest G. MF59 adjuvant enhances the antibody response to recombinant hepatitis B surface antigen vaccine in primates. J Infect Dis 1996; 174:1168.

25. Jacques P, Moens G, Desombere I, et al. The immunogenicity and reactogenicity profile of a candidate hepatitis $B$ vaccine in an adult vaccine non-responder population. Vaccine 2002; 20:3644.

26. Sprengers D, Janssen HLA. Immunomodulatory therapy for chronic hepatitis B virus infection. Fundam Clin Pharmacol 2004;19:17-26

27. Tozun N, Ozdogan OC, Cakaloglu Y, et al. A nationwide prevalance study and risk factors for hepatitis A, B, C and D infections in Turkey. Hepatology Volume 2010; 52 (Supplement S1): 697A.

28. Houghton M. Prospects for prophylactic and therapeutic vaccines against the hepatitis $C$ viruses. Immunol Rev 2011; 239: 99-108.

29. Frey SE, Houghton M, Coates S, et al. Safety and immunogenicity of HCV E1E2 vaccine adjuvanted with MF59 administered to healthy adults. Vaccine 2010; 28: 6367-73.

30. Law LMJ, Landi A, Magee WC, Tyrrell DL, Houghton H. Progress towards a hepatitis $\mathrm{C}$ virus vaccine. Emerging Microbes and Infections 2013;2:e79. doi:10.1038/ emi.2013.79; published online 20 November 2013 